\title{
ZINC CONTAMINATION IS AN UNDERESTIMATED RISK TO AMPHIBIANS: TOXICITY EVALUATION IN TADPOLES OF FEJERVARYA LIMNOCHARIS
}

\author{
Arabinda PATAR ${ }^{1}$, Indranil DAS ${ }^{1}$, Sarbani GIRI ${ }^{2}$, Anirudha GIRI ${ }^{1 *}$ \\ ${ }^{1}$ Environmental and Human Toxicology Laboratory, Department of Life Science and Bioinformatics, \\ Assam University, 788011 Silchar, India \\ ${ }^{2}$ Molecular Genetics Laboratory, Department of Life Science and Bioinformatics, \\ Assam University, 788011 Silchar, India
}

Received 30 October 2020; accepted 12 January 2021

\author{
Highlights \\ $\mathrm{ZnCl}_{2}$ produced concentration dependent mortality to F. limnocharis tadpoles. \\ Sub-lethal $\mathrm{ZnCl}_{2}$ altered metamorphosis time of tadpoles. \\ $\mathrm{ZnCl}_{2}$ induced DNA strand breaks and micronucleus in tadpoles.
}

\begin{abstract}
Aquatic environments are often contaminated with zinc. Amphibian tadpoles are likely to be exposed to high concentrations of zinc present in these environments. We determined the acute and sub-chronic toxicity of $\mathrm{ZnCl}_{2}$ on Fejervarya limnocharis tadpoles under laboratory conditions. The $\mathrm{LC}_{50}$ values of $\mathrm{ZnCl}_{2}$ were found to be 5.81, 4.32, 3.79 and $3.61 \mathrm{mg} / \mathrm{L}$ at $24,48,72$ and $96 \mathrm{~h}$ of exposure respectively. Long-term exposure to sub-lethal concentrations of $\mathrm{ZnCl}_{2}$ induced significant mortality in concentration and time dependent manner. Sub-lethal $\mathrm{ZnCl}_{2}$ exposure significantly altered survival, body length and body weight at metamorphosis. Micronucleus test and comet assay indicated the genotoxic potential of $\mathrm{ZnCl}_{2}$. Significant increase in DNA strand break was observed following $\mathrm{ZnCl}_{2}$ exposure equivalent to $1 \%$ of the of $24 \mathrm{~h} \mathrm{LC}_{50}$ value. The findings indicate possible adverse to tadpoles inhabiting aquatic environments contaminated with zinc. In addition, the findings may be extrapolated to aquatic organisms of similar torphic status.
\end{abstract}

Keywords: zinc, Fejervarya limnocharis, genotoxicity, micronucleus, comet assay.

\section{Introduction}

Heavy metal contamination of aquatic environment is one of the common and persistent forms of pollution. Heavy metals have been identified as one of the significant causative factors of ecological degradation in aquatic habitats (Baldantoni et al., 2004). Aquatic environments are polluted by heavy metals due to natural processes through weathering and leaching of mineral deposits (Purushothaman \& Chakrapani, 2007; Adamu et al., 2015; Skordas et al., 2015) as well as human economic activities (Mohiuddin et al., 2011; Wei \& Yang, 2010).

Zinc is an essential element required for normal metabolic process (Vladimirov, 1969; Frieden, 1972). Besides, zinc is widely used in industry for manufacture of a broad range of products ranging from paints to pharmaceuticals and cosmetics. Other common uses of zinc for economic activities include metal plating, plastic production, electrical components and battery manufacturing. The ambient natural background concentration of zinc in freshwater bodies is less than $50 \mu \mathrm{g} / \mathrm{liter}$. However, concentrations up to $4 \mathrm{mg} / \mathrm{liter}$ in water and $100 \mathrm{mg} / \mathrm{kg}$ dry weight in sediments have been reported in anthropogenically contaminated freshwater habitats (World Health Organization [WHO], 2001; Mondal et al., 2017; Sarkar et al., 2017). Heavy metals are toxic to living organisms. But; unlike other heavy metals such as copper, cadmium, mercury, lead and the metalloid arsenic; zinc has always been considered an underestimated risk factor for aquatic organisms. There are studies, though limited in number, suggesting that aquatic organisms exposed to higher concentrations of zinc could exhibit significant adverse

*Corresponding author. E-mails: agiri123@yahoo.com; girianirudha@gmail.com 
physiological effects (Sinley et al., 1974; Benoit \& Holcombe, 1978; Holcombe et al., 1979; Leland, 1983; WHO, 2001; Brinkman \& Woodling, 2005; Bringolf et al., 2006).

Amphibians are an important group of vertebrates occupying critical positions in many food chains. In fact, in wetland ecosystems, these are often regarded as key stone species. A global assessment has revealed that amphibians are declining rapidly and up to $40 \%$ of the species have been affected in this process (Stuart et al., 2004). Environmental pollution has been identified as one of the major factors of such decline in amphibian species and polulation. The larval stages of amphibians are spent in aquatic habitats especially in shallow ephemeral ponds. Due to shorter water columns in these habitats, the tadpoles of amphibians spent a significant period in the bottom sediments to avoid daytime increase in water temperature. Therefore, they are vulnerable to contaminants present in the water column as well as the pollutant rich bottom sediments.

The worldwide decline in amphibian population has attracted increasing attention from scientists in recent years (Beebee \& Griffiths, 2005). Several studies have shown that heavy metals adversely produce lethal and sub-lethal toxicity in amphibians. Surprisingly, little or no information is available on the possible toxic effects of zinc in anuran amphibians. In the present study, we have examined the effects of zinc on the tadpoles of $F$. limnocharis. The systematic analysis of multiple toxicological endpoints covering acute toxicity, changes in life history traits and genotoxicity provides important toxicological insights into this otherwise lesser-known heavy metal in amphibians.

\section{Materials and methods}

\subsection{Collection, rearing and maintenance of study animal}

F. limnocharis tadpoles were collected from an artificial captive breeding pond near the Assam University, Silchar campus which is not contaminated by any source of contaminant exposure. Tadpole rearing was done as described earlier (Giri et al., 2012). Prior to experiments, the tadpoles were subjected to acclimation in the laboratory in aerated medium for 48 - $h$. These were screened to identify and separate the tadpoles belonging to different Gosner stages (Gosner, 1960). The experiments were performed at $26 \pm 1{ }^{\circ} \mathrm{C}$ and 12 -h light and dark cycles. Grinded fish food were used to feed the tadpoles without any restriction. Chemically pure salts of $\mathrm{ZnCl}_{2}$ dissolved in distilled water was used as the test agent. $\mathrm{ZnCl}_{2}$ (mol wt. 136.30; $\geq 95 \%$ pure, CAS Registry No. 7646-85-7) were purchased from Merck Specialities Private Limited, Mumbai, India. The study has ethical clearance of the Assam University through approval letter AUS/IAEC/2017/PC/02.

\subsection{Acute toxicity studies and determination of $\mathrm{LC}_{50}$}

Acute toxicity experiments were performed in polypropylene tubs containing $2 \mathrm{~L}$ of aged well water. Each tub housed 10 tadpoles. The tadpoles belonging to Gosner stage 22-25 were subjected to either no treatment or exposed to four different concentrations $(3,4,5$ and $6 \mathrm{mg} / \mathrm{L})$ of $\mathrm{ZnCl}_{2}$. The five treatment conditions were replicated thrice for a total of 15 experimental units. At $24 \mathrm{~h}$ intervals, for the next $96 \mathrm{~h}$, experimental tubs were monitored and any dead individuals were carefully removed keeping record for each. The tadpole survival data was used to calculate the $\mathrm{LC}_{50}$ values at different time points using probit analysis.

\subsection{Chronic exposure and toxicity studies}

Chronic toxicity evaluations were also made in polypropelyne tubs following sub-lethal $\mathrm{ZnCl}_{2}$ concentrations over longer period of time. The tadpoles of Gosner developmental stage 22-25 were exposed to four different sub-lethal concentrations $(0.5,1.0,1.5$ and $2.0 \mathrm{mg} / \mathrm{L})$ of $\mathrm{ZnCl}_{2}$ approximately ranging between $10 \%$ and $35 \%$ of the $24 \mathrm{~h} \mathrm{LC}_{50}$ values. The control groups were not exposed to any kind of treatment. The five treatment conditions were replicated thrice for a total of 15 experimental units. The tub water was changed every alternate day and $\mathrm{ZnCl}_{2}$ was reapplied in to the respective tubs. The experiments were terminated following either death or metamorphosis of all individuals in the experimental groups. Survival status of the tadpoles recorded on daily basis and deceased ones were removed. On day 23, the first metamorphosis occurred. Therefore, the tadpole survival data for the first 23 days of the exposure period among various treatment groups were compared. In addition, survival percentage at metamorphosis as well as average time to metamorphosis in each group was determined. In addition, the average body weight as well as snout to vent length (SVL) of the newly metamorphosed froglets were measure in each treatment group. The metamorphosed froglets were examined for major morphological defects if any and noted. The water parameters were regularly monitored during the course of the experiments. Dissolved oxygen content was always $>8.4 \mathrm{mg} / \mathrm{L}$ and $\mathrm{pH}$ varied between 7.4 and 7.6.

Kaplan-Meier test was used to compare the survival percentage among the treatment groups. Time to metamorphosis as well as morphometric parameters such as SVL and body weight of the metamorphosed individuals were analyzed using ANOVA. Post hoc analysis (Tukey'sHSD) was also performed to compare among the treatment groups. Statistical analyses were performed at $95 \%$ confidence interval using the 18.0 version of SPSS statistical software.

\subsection{Micronucleus test}

Amphibian erythrocytes are nucleated and multiply in the circulation during larval stages (Duellman \& Trueb, 1986). Therefore, erythrocytes cells are suitable for micronuclei (MN) detection which can be readily counted in blood smears (Campana et al., 2003; Giri et al., 2012). The MN assay was performed in peripheral blood erythrocytes as described previously (Giri et al., 2012). The tadpoles of 
Gosner stage 26-28 were selected. During this developmental period, intense hematopoiesis takes place which is suitable for genotoxicity studies. This experiment was performed in polypropylene tubs containing $2 \mathrm{~L}$ of aged well water as described earlier. The tadpoles were exposed to four different concentrations of $\mathrm{ZnCl}_{2}(0.5,1.0,1.5$ and $2.0 \mathrm{mg} / \mathrm{L}$ ). Negative (no treatment) and positive (cyclophosphamide $2 \mathrm{mg} / \mathrm{L}$ ) control groups were included with the exposure groups. The six treatment conditions were replicated thrice for a total of 18 experimental units. After $24,48,72$ and $96-\mathrm{h}$ of the treatments, 5 live tadpoles from each group were anesthetized in 4\% buffered MS222. At least 2 smears per tadpole were made with peripheral blood. The blood smears were fixed in absolute methanol for $3 \mathrm{~min}$ and air-dried. A day later the slides were coded and stained in buffered Giemsa (10\%). Analysis of MN was carried out in 1000 cells per tadpole under the microscope at a final magnification of $1000 \mathrm{X}$. The scoring criteria was similar to those described by Lajmanovich et al. (2005). ANOVA was used to analyze change in MN frequency at different concentration levels and time points. Treatment effects on MN frequency was assessed using linear regression analysis.

\subsection{Comet assay}

This experiment was performed for the investigation of DNA damage (single-, double-strand breakage) under alkaline condition at the individual cell level by following the protocol of Singh et al. (1988) with subsequent modifications of Tice et al. (2000). In brief, tadpoles Gosner stage $26-28$ were exposed to $58.08 \mu \mathrm{g} / \mathrm{L}$ ( $1 \%$ of $24-\mathrm{h} \mathrm{LC}_{50}$ value) of $\mathrm{ZnCl}_{2}$. The use of this concentration is intended to determine the genotoxic potential of $\mathrm{ZnCl}_{2}$ at environmentally relevant concentration which otherwise may not be detected by the $\mathrm{MN}$ test. There were 6 tadpoles in each treatment group ( 3 in each experiment repeated twice).

Cardiac blood collected following 24-h of exposure was mixed with calcium and magnesium free PBS ( $\mathrm{pH}$ 7.4). An aliquot of cell suspension containing $10^{6} \mathrm{cells} / \mathrm{ml}$ was diluted in low melting agarose in a ratio of 1:10. Aliquots of $85 \mu \mathrm{l}$ of the mixture were rapidly spread on precoated frosted slides and allowed to polymerize in dark. Then, the slides were immersed in freshly prepared ice-cold lysing solution ( $\mathrm{pH}$ 10) containing $10 \mathrm{mM}$ Trizma base, $10 \%$ DMSO, 100 mM Na 2 EDTA, $2.5 \mathrm{M} \mathrm{NaCl}, 1 \%$ TritonX100. DNA unwinding process was allowed to take place for 20 minutes at $\mathrm{pH} 13.5$ in fresh electrophoresis buffer consisting of $300 \mathrm{mM} \mathrm{NaOH}$ in $1 \mathrm{mM} \mathrm{Na}_{2}$ EDTA in the electrophoresis chamber. Electrophoresis was carried out at a constant voltage of $24 \mathrm{~V}$ and $300 \mathrm{~mA}$ at $4{ }^{\circ} \mathrm{C}$ for $20 \mathrm{~min}$. Then the slides were transferred to the neutralizing buffer (Tris- $\mathrm{HCl}, \mathrm{pH}$ 7.5) and kept in dark. The neutralizing solution was changed at 5 minutes intervals for thrice. The slides were stained in $20 \mu \mathrm{g} / \mathrm{ml} \mathrm{EtBr}$ followed by rinsing in double distilled water to remove the unbound EtBr. Kinetic imaging image analysis system (Komet 5.5, Andor Technology, Nottingham, UK) was used for quantitative analysis of DNA damage in the cells. A charge coupled device (CCD) camera as part of Leica fluorescence microscope (Wetzlar, Germany) was used to acquire the images for analysis by the software. The final magnification was $400 \times$. Comet data was analyzed using 2-tailed Student's t-test.

\section{Results}

\subsection{Acute toxicity studies and determination of $\mathrm{LC}_{50}$}

The acute $\mathrm{LC}_{50}$ values of $\mathrm{ZnCl}_{2}$ in $F$. limnocharis were found to be $5.81,4.32,3.79$ and $3.61 \mathrm{mg} / \mathrm{L}$ respectively at 24, 48, 72 and $96 \mathrm{~h}$ (Table 1). None of the animals in the control group died. As the exposure period increased, the $\mathrm{LC}_{50}$ values decreased in a linear manner. Linear regression analysis of the mean lethal concentration showed significant $\left(R^{2}=0.851, p<0.05\right)$ concentration and time effect.

Table 1. $\mathrm{LC}_{50}$ values of $\mathrm{ZnCl}_{2}$ in F. limnocharis tadpoles

\begin{tabular}{|l|c|}
\hline \multicolumn{1}{|c|}{ Duration of exposure } & LC $_{50}$ value $(\mathrm{mg} / \mathrm{L})$ \\
\hline 24 hour & 5.81 \\
\hline 48 hour & 4.32 \\
\hline 72 hour & 3.79 \\
\hline 96 hour & 3.61 \\
\hline
\end{tabular}

\subsection{Chronic toxicity studies on tadpole survival, growth and development}

Tadpoles of F. limnocharis exposed to sublethal concentrations of $\mathrm{ZnCl}_{2}$ caused increased rate of mortality which was both concentration and time dependent (Figure 1). In the overall comparison of the 23-days tadpole survival data, $\mathrm{ZnCl}_{2}$ had significant $(\mathrm{p}<0.001)$ effect as revealed by Kaplan-Meier product limit estimate. $\mathrm{ZnCl}_{2}$ at highest concentration $(2 \mathrm{mg} / \mathrm{L})$ used in the present study could exhibit only $33 \%$ survival up to day 23 following the exposure.

In comparison to the control, the metamorphosis time in the groups exposed to sub-lethal concentrations

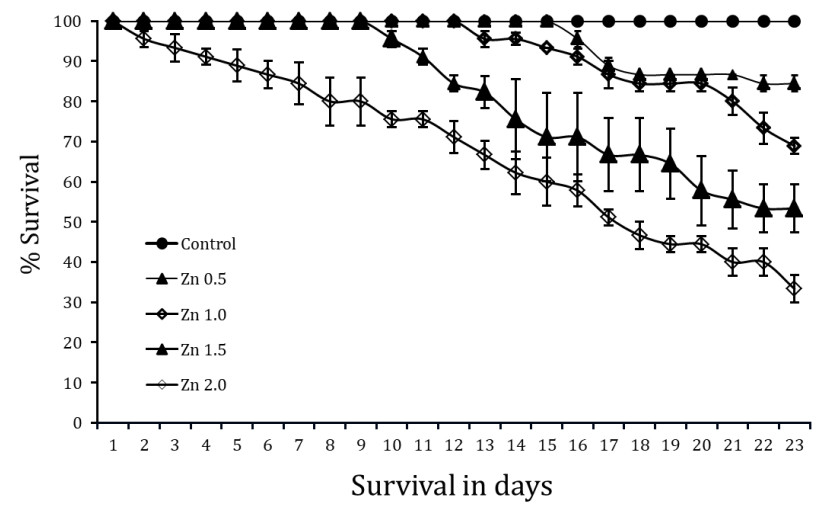

Figure 1. Survival of tadpoles of $F$. limnocharis after $23 \mathrm{~d}$ of exposure to different sub-lethal concentrations of $\mathrm{ZnCl}_{2}$. Values are mean \pm SE 
of $\mathrm{ZnCl}_{2}$ was significantly delayed (Figure 2). The metamorphosis pattern was monitored up to 50 days till all of the tadpoles either metamorphosed or died due to toxicity. Tadpoles exposed to the lowest concentration of 0.05 $\mathrm{mg} / \mathrm{L}$ of $\mathrm{ZnCl}_{2}$ took significantly more time to metamorphose. However, those exposed to $2 \mathrm{mg} / \mathrm{L}$ was failed to metamorphose and caused $100 \%$ mortality within 28 days of the exposure (Figure 2). The average metamorphosis time in the exposed group receiving $0.5 \mathrm{mg} / \mathrm{L}$ of $\mathrm{ZnCl}_{2}$ was significantly higher $(\mathrm{p}<0.05)$ as compared to control

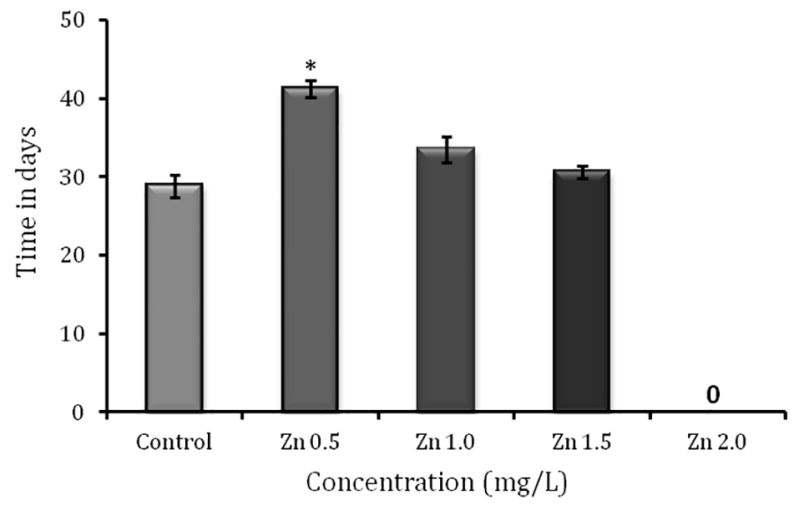

Figure 2. Time taken by tadpoles to metamorphose following exposure to different concentrations of $\mathrm{ZnCl}_{2}$. Data are significantly different from control (ANOVA). $\left.{ }^{*}\right)=p<0.05$

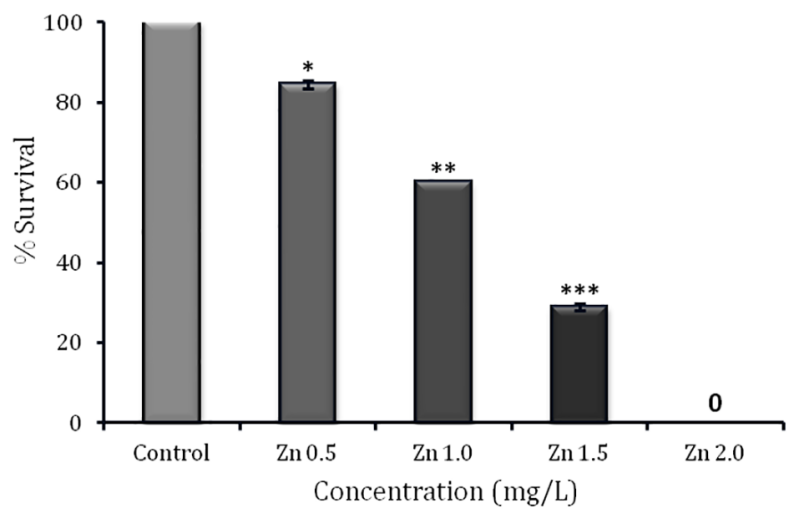

Figure $4 . \mathrm{ZnCl}_{2}$ induced changes body weight (A) and snout to vent length (B) of froglets at metamorphosis. Data are significantly different from the control group at $\mathrm{p}<0.05\left(^{*}\right)$ group. Tadpoles in the control group took an average time of $28.87 \pm 1.42$ days for metamorphosis.

Tadpoles exposed to highest concentrations of $\mathrm{ZnCl}_{2}$ such as $2 \mathrm{mg} / \mathrm{L}$ did not survive till metamorphosis (Figure 3). The number of tadpoles which survived till metamorphosis was dependent on the concentration of $\mathrm{ZnCl}_{2}$ (one-way ANOVA, $\mathrm{F}_{4,70}=390.026, \mathrm{p}<0.001$ ).

The average body weight of the metamorphosed froglets in the $\mathrm{ZnCl}_{2}$ exposed groups was found to be apparently higher than in the control group (Figure 4A). However, these were not statistically significant. The snout to vent length of the metamorphosed froglets is often used as standard measure of body length indicative of skeletal growth. In contrast to body weight, Tukey's pair wise comparison test indicated that at lower concentrations, zinc chloride caused significant $(\mathrm{p}<0.05)$ increased in snout vent length of metamorphosed froglets at metamorphosis (Figre $4 \mathrm{~B}$ ). $\mathrm{ZnCl}_{2}$ in the concentration ranges tested did not cause any other apparent malformations in any of the exposed groups. However, a few cases of abdominal edema were observed in the groups exposed higher concentrations of $\mathrm{ZnCl}_{2}$.

Table 2. Incidence of micronucleated erythrocytes induced by $\mathrm{ZnCl}_{2}$ in tadpoles ${ }^{\mathrm{a}, \mathrm{b}, \mathrm{c}}$

\begin{tabular}{|c|c|c|c|c|}
\hline \multirow{2}{*}{$\begin{array}{c}\text { Concen- } \\
\text { tration }\end{array}$} & \multicolumn{4}{|c|}{ Exposure period } \\
\hline & $24 \mathrm{~h}$ & $48 \mathrm{~h}$ & $72 \mathrm{~h}$ & $96 \mathrm{~h}$ \\
\hline Control & $0.30 \pm 0.06$ & $0.25 \pm 0.13$ & $0.33 \pm 0.06$ & $0.25 \pm 0.13$ \\
\hline $\begin{array}{l}\mathrm{CP} 2 \\
\mathrm{mg} / \mathrm{L}\end{array}$ & $11.67 \pm 0.66$ & $13.93 \pm 0.42$ & $13.47 \pm 0.49$ & $13.13 \pm 0.53$ \\
\hline \multicolumn{5}{|c|}{ Zinc chloride } \\
\hline $0.5 \mathrm{mg} / \mathrm{L}$ & $0.33 \pm 0.10$ & $0.45 \pm 0.10$ & $0.56 \pm 0.06^{*}$ & $0.45 \pm 0.10$ \\
\hline $1.0 \mathrm{mg} / \mathrm{L}$ & $0.40 \pm 0.06$ & $0.80 \pm 0.13^{*}$ & $0.93 \pm 0.13^{* *}$ & $1.00 \pm 0.16^{* * *}$ \\
\hline $1.5 \mathrm{mg} / \mathrm{L}$ & $0.60 \pm 0.06^{\star}$ & $1.18 \pm 0.19^{* * *}$ & $1.20 \pm 0.13^{* * *}$ & $1.33 \pm 0.06^{* * *}$ \\
\hline $2.0 \mathrm{mg} / \mathrm{L}$ & $1.00 \pm 0.13^{* * *}$ & $1.45 \pm 0.06^{* * *}$ & $1.50 \pm 0.13^{* * *}$ & $1.53 \pm 0.10^{* * *}$ \\
\hline
\end{tabular}

Note: ${ }^{\text {a }}$ Control: no treatment was given; CP: cyclophosphamide (positive control); ${ }^{\mathrm{b}}$ Values are frequency of micronucleated erythrocytes (\%) expressed as means \pm SE based on 1000 cells per animal $(\mathrm{n}=15) ;{ }^{\mathrm{c}}$ Level of significance from respective control values: ${ }^{*}=\mathrm{p}<0.05:{ }^{* *}=\mathrm{p}<0.01:{ }^{* * *}=\mathrm{p}<0.001$. Statistical analysis: ANOVA.
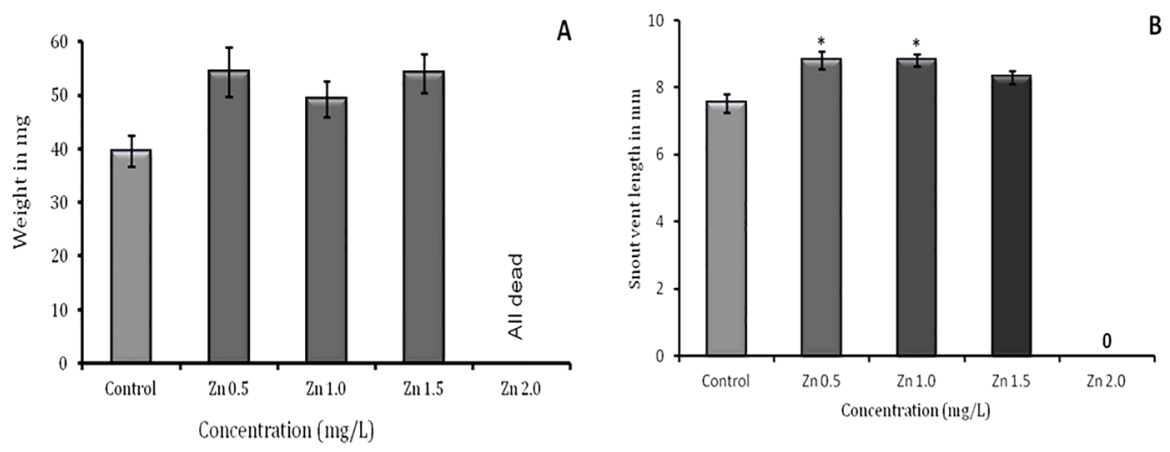

Figure 4. $\mathrm{ZnCl}_{2}$ induced changes body weight (A) and snout to vent length (B) of froglets at metamorphosis. Data are significantly different from the control group at $\mathrm{p}<0.05\left(^{*}\right)$ 


\subsection{Micronucleus test}

$\mathrm{ZnCl}_{2}$ exposure induced $\mathrm{MN}$ in the erythrocytes of $\mathrm{F}$. limnocharis tadpoles (Table 2$)$ at $24 \mathrm{~h}\left(\mathrm{~F}_{4}, 70=9.82, \mathrm{p}<0.05\right)$, $48 \mathrm{~h}\left(\mathrm{~F}_{4}, 70=33.78, \mathrm{p}<0.01\right), 72 \mathrm{~h}\left(\mathrm{~F}_{4}, 70=42.46, \mathrm{p}<0.001\right)$, and $96 \mathrm{~h}\left(\mathrm{~F}_{4}, 70=47.53, \mathrm{p}<0.01\right)$. There were significant positive correlations between the concentrations of $\mathrm{ZnCl}_{2}$ and micronucleus frequency (Figure 5). The correlation coefficients at $24 \mathrm{~h}, 48 \mathrm{~h}, 72 \mathrm{~h}$ and $96 \mathrm{~h}$ were $0.9117(\mathrm{p}<$ $0.01), 0.9955(\mathrm{p}<0.001), 0.9981(\mathrm{p}<0.001)$ and 0.9864 $(\mathrm{p}<0.001)$ respectively. In the time response study, except for $0.5 \mathrm{mg} / \mathrm{L}$ of $\mathrm{ZnCl}_{2}(\mathrm{r}=0.6361)$ all the other treatments tested showed time dependent increase in the frequency of MN all through the 96h study period. Moreover, it was found that that the overall time effect on micronucleus induction (ANOVA) was statistically significant $\left(\mathrm{F}_{4,295}=\right.$ $4.82, \mathrm{p}<0.05)$.

\subsection{Comet analysis}

Erythrocytes of F. limnocharis tadpoles showed significant change in the degree of DNA damage following $\mathrm{ZnCl}_{2}$ exposure as evidenced by changes in comet parameters (Figure 6). Quantitative analysis revealed that amount of DNA
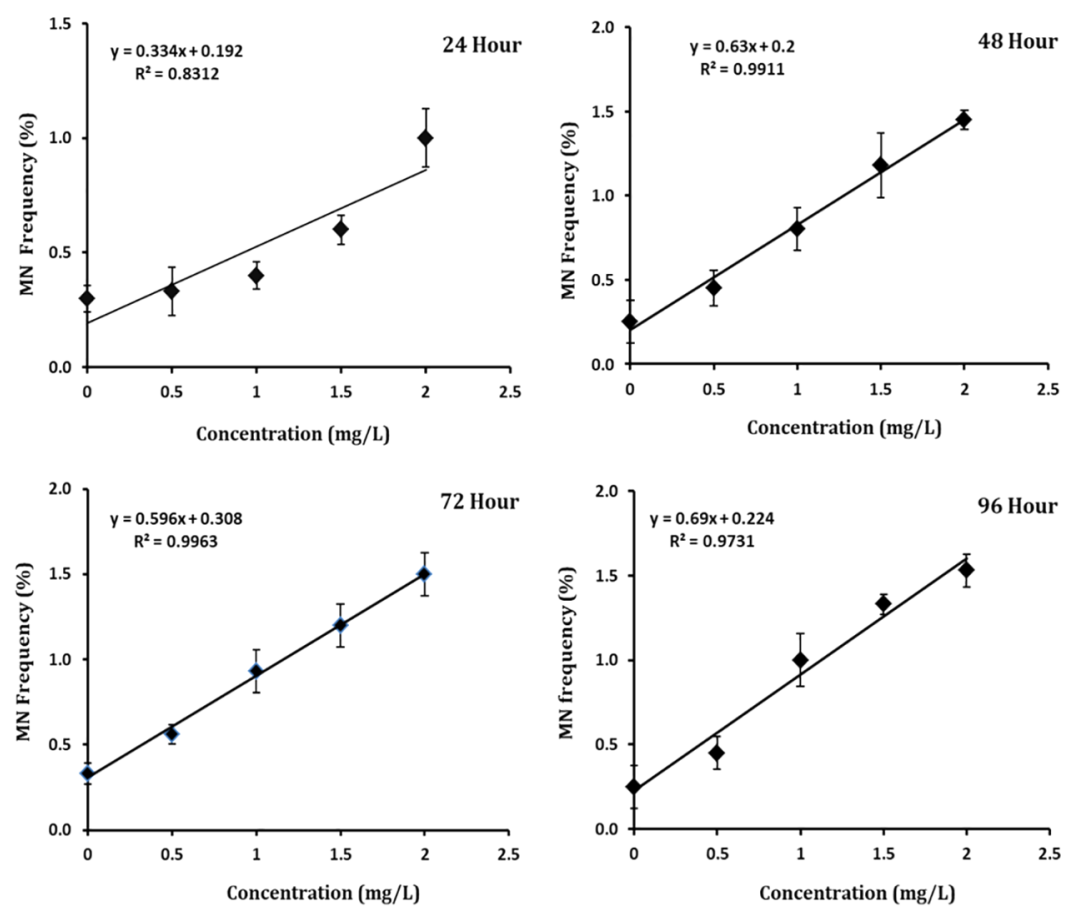

Figure 5. Regression plot and $\mathrm{R}^{2}$ of micronucleated erythrocytes at $24 \mathrm{~h}, 48 \mathrm{~h}, 72 \mathrm{~h}$ and $96 \mathrm{~h}$ of zinc chloride treatment
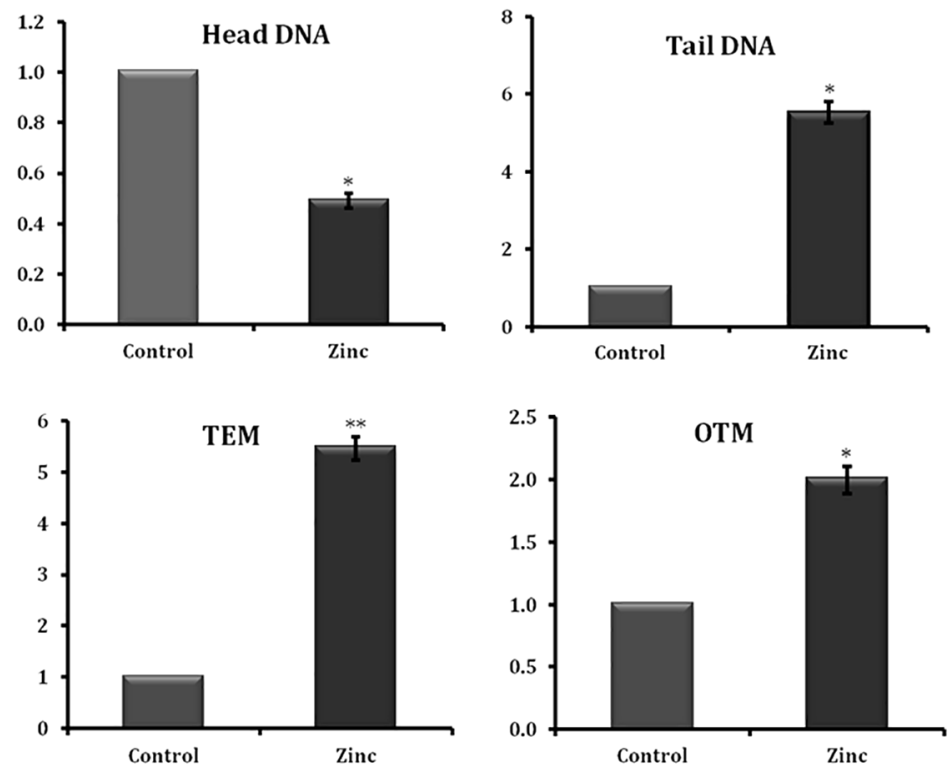

Figure 6. Comparison of comet parameters (fold change) between control and $\mathrm{ZnCl}_{2}$ exposed groups. OTM: olive tail moment; TEM: tail extent moment. Values are significantly different from control: $\left.\mathrm{p}<0.05{ }^{(}\right)$and $\mathrm{p}<0.001\left(^{* *}\right)$ 
present in comet head region significantly decreased $(\mathrm{p}<$ $0.05)$ with concurrent increase in the tail region $(\mathrm{p}<0.05)$ compared to the control group. Olive tail moment (OTM) in a comet represents the product of the amount of DNA in the tail region as well as the average distance they migrate in the gel. In the present study, the OTM in the $\mathrm{ZnCl}_{2}$ exposed cells was significantly higher $(\mathrm{p}<0.05)$ compared to the control cells.

\section{Discussion}

The present study evaluated acute and subchronic toxicity of $\mathrm{ZnCl}_{2}$ in tadpoles of $F$. limnocharis. It was found that tadpole mortality rate was positively correlated with exposure to $\mathrm{ZnCl}_{2}$ concentration. The calculated $96 \mathrm{~h} \mathrm{LC}_{50}$ value of $\mathrm{ZnCl}_{2}$ in the current study was found to be $3.61 \mathrm{mg} / \mathrm{L}$ (Table 1). Similar $\mathrm{LC}_{50}$ value was also found in the earlier studies by Svecevičius (1999). Bagdonas and Vosylienè (2006) reported that the $96 \mathrm{~h} \mathrm{LC}_{50}$ value of zinc in Rainbow trout (Oncorhynchus mykiss) was $3.79 \mathrm{mg} / \mathrm{L}$. The $\mathrm{LC}_{50}$ values for $\mathrm{ZnCl}_{2}$ found in the present study are similar to those previously reported in tadpoles by Khangarot and Ray (1987) and Shuhaimi-Othman et al. (2012). The LC $_{50}$ values for zinc have been shown to vary over a wide range depending upon the species and developmental stages. For example, the $96 \mathrm{~h} \mathrm{LC}_{50}$ values was reported to be $2.1 \mathrm{mg} / \mathrm{L}$ for Rana hexadactyla and $28.38 \mathrm{mg} / \mathrm{L}$ for Rana luteiventris (Khangarot et al., 1985; Lefcort et al., 1998). However, available literature also reported that the most published $\mathrm{LC}_{50}$ values for other amphibian tadpoles are greater than $19 \mathrm{mg} / \mathrm{L}$ (Linder \& Grillitsch, 2000). One possible reason for this wide range of $\mathrm{LC}_{50}$ data is due to the fact that toxicity of $\mathrm{Zn}$ ions is highly dependent on water hardness; the highest $\mathrm{LC}_{50}$ value available in the literature was observed when concentration of calcium ions are at their highest (Skidmore, 1964). Moreover, other possible reason for this is due to the experimental methods conducted in each study such as body size or body length/developmental stage, body masses of tadpoles and temperature etc.

In the present study, long term exposure at sublethal concentrations $(0.5-2.0 \mathrm{mg} / \mathrm{L})$ of $\mathrm{ZnCl}_{2}$ to Flimnocharis tadpoles demonstrate that the percentage of tadpole survival decreased significantly with increasing metal concentrations (Figure 1). Interestingly, there was a significant interaction between increasing $\mathrm{ZnCl}_{2}$ concentration and the duration of exposure of the tadpoles. Tadpoles exposed to highest sub-lethal concentration of $\mathrm{ZnCl}_{2}(2 \mathrm{mg} / \mathrm{L})$ did not survive till metamorphosis which suggests that tadpole survival was dependent on metal treatment (Figure 2). This may be due to the fact that the reduced growth rates of tadpoles at high metal concentrations are caused by increased metabolic costs, which leaves little energy for growth (Rowe et al., 1998). Studies extending for longer periods have shown that metal exposure reduces tadpole survival to metamorphosis (Lefcort et al., 1998). Our results demonstrate that sub-lethal concentrations of $\mathrm{ZnCl}_{2}$ significantly delayed the time to metamorphosis process
(Figure 3). Similar findings have been reported in earlier studies with zinc and copper metal ion exposure on the germination of frogs spawn and on growth of tadpole (Dilling \& Healey, 1926). Lefcort et al. (1998) reported that low levels of lead, zinc and cadmium did not significantly delay time to metamorphosis, but the low lead and low zinc exposed animals underwent metamorphosis at a lower mass than control tadpoles. In fishes such as fathead minnow (Brungs, 1969), zebrafish (Dave et al., 1987) and the flounder Paralichthys olivaceus (Yulin et al., 1990), zinc has been reported to delay the time-to-hatch.

The standard measurement of body length is an important parameter to determine the skeletal growth of metamorphosed froglets at metamorphosis. Our study demonstrate that at low concentrations $(0.5$ and $1.0 \mathrm{mg} / \mathrm{L})$ of $\mathrm{ZnCl}_{2}$ significantly increased body length of metamorphosed froglets (Figure 4B). Contrary to our findings, some reports suggest that body length of metamorphosed froglets is not influenced by exposure to lower concentrations of zinc. However, as metal concentrations increased, tadpole body length decreased significantly (Lefcort et al., 1998; Haywood et al., 2004). Therefore, it is evident that there exists species specific sensitivity among different anuran species to a given toxicant. Morphological and physiological abnormalities in amphibians exposed to toxicants have been well-studied (Stebler et al., 1988; Bantle et al., 1989; Hopkins et al., 2000). However, the mechanisms by which zinc influences amphibian metamorphosis remain unclear.

The micronucleus test in erythrocytes of anuran tadpoles is widely used in experimental models for the biomonitoring studies as a sensitive biomarker of environment contaminant induced genotoxicity in aquatic organisms. MN test has served as an index of cytogenetic damage for over 30 years (Fenech et al., 2003). In the present study, $\mathrm{ZnCl}_{2}$ was found to be genotoxic in the micronucleus test in tadpoles of $F$. limnocharis. It was observed that the frequency of micronucleus increased with increasing exposure concentration of $\mathrm{ZnCl}_{2}$ (Table 2). Similar findings have been reported in earlier studies (Wei et al., 2015) in Rana zhenhaiensis tadpoles exposed to $\mathrm{Zn}^{+2}$. Earlier studies by Bagdonas and Vosylienè (2006) reported genotoxicity of $\mathrm{Cu}, \mathrm{Zn}$ in $\mathrm{MN}$ test in rainbow trout erythrocytes; but there were no dose-dependent changes in micronucleated erythrocytes. Similar result has been found in our previous studies with cadmium chloride exposure on Rana limnocharis tadpoles (Patar et al., 2016). The present findings are in agreement with majority of previously reported studies with pesticides and heavy metals in $X$. laevis larvae, R. limnocharis, E. cyanophlyctis and Bullfrog tadpoles (Mouchet et al., 2006; Giri et al., 2012; Yadav et al., 2013; Montalvão \& Malafaia, 2017). Apart from amphibian tadpoles, MN test in experimental fish models have been well documented. Obiakor et al. (2010) conducted MN test on Synodontis clarias and Tilapia nilotica species and reported that zinc exposure caused significant increase in the frequency of micronucleated erythrocytes 
produced in both the species. Bakar et al. (2014) demonstrated that zinc exposure to Oreochromis niloticus species produced significant increased induction of $\mathrm{MN}$ and erythrocytes with nuclear abnormalities compared with the control group.

$\mathrm{MN}$ induction is an indicator of altered cytogenetic effects reflecting changes in chromosome number and/ or structure. These lost chromosome(s) or chromosomal fragment(s) fail to participate in the anaphasic movement, thus fail to be part of the main nucleus (Muranli \& Güner, 2011). On the other hand, comet assay (CA) is used to detect double or single DNA strand breaks in the interphase nuclei. CA is widely used in field monitoring and in laboratory experiments to demonstrate the sensitivity of aquatic organisms to genotoxic agents (Clements et al., 1997; Mouchet, 2002; Mouchet et al., 2005, 2007; Frenzilli et al., 2009; Singha et al., 2014; Patar et al., 2016). In the present study, $\mathrm{ZnCl}_{2}$ exposed groups clearly demonstrate that zinc induces a considerable amount of DNA strands breaks in F. limnocharis at very low concentration. The DNA damage is indicated by significant alterations in various comet parameters (Figure 6). Compared to other heavy metals namely $\mathrm{Cd}$ and $\mathrm{Cu}$; studies on the genotoxic potential of zinc in amphibian tadpoles using comet assays are infrequent. However, using this sensitive tool, genotoxic potential of zinc have been shown in various model organisms such as fish and mice as well as in human cells (Banu et al., 2001; Ho \& Ames, 2002; Ho et al., 2003; Zhang et al., 2008; Sliwinski et al., 2009). All in all, the present findings on genotoxicity analysis suggest the genotoxic potential of $\mathrm{ZnCl}_{2}$ in $F$. limnocharis tadpoles.

Several studies have assessed the genotoxicity of zinc chloride following oral or parental exposure in various multicellular organisms. In vitro studies have shown that zinc exposure to induce DNA damage. Using comet assay Banu et al. (2001) have shown that zinc produces DNA single strand breaks in vivo. In human lung cells, it has been shown that DNA double strand breaks as well as chromosomal instability occur following exposure to higher concentrations of zinc (Xie et al., 2009). Similar effects have been shown in bone marrow cells following zinc exposure in vivo (Vilkina et al., 1978). KowalskaWochna et al. (1988) reported that zinc chlorate given to rats in drinking water at a dose rate of $14.8 \mathrm{mg} / \mathrm{kg} /$ day caused significant damage to the gentic material. Genotoxic effects of zinc administered either intraperitoneally (Gupta et al., 1991) or by inhalation (Voroshilin et al., 1978) have also been reported in mice test system. However, the Agency for Toxic Substances and Disease Registry [ATSDR] (1990) report provides indication of zinc to be a weak clastogenic agent. Several studies also have reported that high zinc concentrations can interfere with ROS detoxification processes and thus contributes to ROS accumulation (Nzengue et al., 2011). However, the underlying molecular mechanism of zinc-induced genotoxicity is poorly understood and requires further investigations.

\section{Conclusions}

In conclusion, this present study provides important information regarding acute and sub-chronic toxicity of $\mathrm{ZnCl}_{2}$ to larval amphibians adding to the present scientific knowledge. But; there is a paucity of information about sub-lethal effects of zinc on the early stages of amphibian development. Therefore, further investigations are essential using more different sub-lethal concentrations of $\mathrm{ZnCl}_{2}$ in aquatic organisms especially in amphibian. All in all, this study suggests the possible role of heavy metal pollution such as zinc towards amphibian population decline and could have similar effects in other aquatic organisms.

\section{Acknowledgements}

Author thankful to Dr. Krishna Bhuyan for reviewing the manuscript. Besides, the financial assistance given by the University Grants Commission, New Delhi under National Fellowship for Higher Education of ST Students, vide grant no. F1-17.1/2016-17/NFST-2015-17-ST-ASS-3758 is thankfully acknowledged.

\section{Author contributions}

The contribution of authors are as follows. AP - planning, experiments, analysis and manuscript writing; ID - experiments and analysis; SG - planning, evaluation and manuscript writing; AG - planning, data analysis and manuscript writing.

\section{Conflict of interest statement}

The authors declare no conflict of interest.

\section{References}

Adamu, C., Nganje, T., \& Edet, A. (2015). Heavy metal contamination and health risk assessment associated with abandoned barite mines in Cross River State, southeastern Nigeria. Environmental Nanotechnology, Monitoring \& Management, 3, 10-21. https://doi.org/10.1016/j.enmm.2014.11.001

Agency for Toxic Substances and Disease Registry. (1990). Toxicological profile for zinc. ATSDR, Atlanta, Georgia, USA. https://www.atsdr.cdc.gov/toxprofiles/tp60.pdf

Bagdonas, E., \& Vosyliene, M. Z. (2006). A study of toxicity and genotoxicity of copper, zinc and their mixture to rainbow trout (Oncorhynchus mykiss). Biologija, 1, 8-13. http://www. elibrary.lt/resursai/LMA/Biologija/Bio_008_013.pdf

Bakar, S., Ashriya, A., Shuib, A., \& Razak, S. (2014). Genotoxic effect of zinc and cadmium following single and binary mixture exposures in tilapia (Oreochromis niloticus) using micronucleus test. Sains Malaysiana, 43(7), 1053-1059.

Baldantoni, D., Alfani, A., Di Tommasi, P., Bartoli, G., \& De Santo, A. V. (2004). Assessment of macro and microelement accumulation capability of two aquatic plants. Environmental Pollution, 130(2), 149-156.

https://doi.org/10.1016/j.envpol.2003.12.015

Bantle, J. A., Fort, D. J., \& James, B. L. (1989). Identification of developmental toxicants using the Frog Embryo Tera- 
togenesis Assay-Xenopus (FETAX). In M. Munawar, G. Dixon, C. I. Mayfield, T. Reynoldson, \& M. H. Sadar (Eds.), Developments in hydrobiology: Vol. 54. Environmental bioassay techniques and their application (pp. 577-585). Springer. https://doi.org/10.1007/978-94-009-1896-2_59

Banu, B. S., Devi, K. D., Mahboob, M., \& Jamil, K. (2001). In vivo genotoxic effect of zinc sulfate in mouse peripheral blood leukocytes using comet assay. Drug and Chemical Toxicology, 24(1), 63-73. https://doi.org/10.1081/DCT-100103086

Beebee, T. J., \& Griffiths, R. A. (2005). The amphibian decline crisis: A watershed for conservation biology? Biological Conservation, 125(3), 271-285.

https://doi.org/10.1016/j.biocon.2005.04.009

Benoit, D. A., \& Holcombe, G. (1978). Toxic effects of zinc on fathead minnows Pimephales promelas in soft water. Journal of Fish Biology, 13(6), 701-708. https://doi.org/10.1111/j.1095-8649.1978.tb03484.x

Bringolf, R. B., Morris, B. A., Boese, C. J., Santore, R. C., Allen, H. E., \& Meyer, J. S. (2006). Influence of dissolved organic matter on acute toxicity of zinc to larval fathead minnows (Pimephales promelas). Archives of Environmental Contamination and Toxicology, 51, 438-444.

https://doi.org/10.1007/s00244-005-0088-6

Brinkman, S., \& Woodling, J. (2005). Zinc toxicity to the mottled sculpin (Cottus bairdt) in high hardness water. Environmental Toxicology and Chemistry, 24(6), 1515-1517. https://doi.org/10.1897/04-235R.1

Brungs, W. A. (1969). Chronic toxicity of zinc to the fathead minnow, Pimephales promelas Rafinesque. Transactions of the American Fisheries Society, 98(2), 272-279. https://doi. org/10.1577/1548-8659(1969)98[272:CTOZTT]2.0.CO;2

Campana, M. A., Panzeri, A. M., Moreno, V. J., \& Dulout, F. N. (2003). Micronuclei induction in Rana catesbeiana tadpoles by the pyrethroid insecticide lambda-cyhalothrin. Genetics and Molecular Biology, 26(1), 99-103.

https://doi.org/10.1590/S1415-47572003000100016

Clements, C., Ralph, S., \& Petras, M. (1997). Genotoxicity of select herbicides in Rana catesbeiana tadpoles using the alkaline single cell gel DNA electrophoresis (comet) assay. Environmental and Molecular Mutagenesis, 29(3), 277-288.

https://doi.org/10.1002/(SICI)1098-2280(1997)29:3<277::AIDEM8>3.0.CO;2-9

Dave, G., Damgaard, B., Grande, M., Martelin, J. E., Rosander, B., \& Viktor, T. (1987). Ring test of an embryo-larval toxicity test with zebrafish (brachydanio rerio) using chromium and zinc as toxicants. Environmental Toxicology and Chemistry, 6(1), 61-71. https://doi.org/10.1002/etc.5620060108

Dilling, W. J., \& Healey, C. (1926). Influence of lead and the metallic ions of copper, zinc, thorium, beryllium and thallium on the germination of frogs' spawn and on the growth of tadpoles. Annals of Applied Biology, 13(2), 177-188. https://doi.org/10.1111/j.1744-7348.1926.tb04262.x

Duellman, W., \& Trueb, L. (1986). Biology of amphibians. McGraw Hill.

Fenech, M., Chang, W. P., Kirsch-Volders, M., Holland, N., Bonassi, S., \& Zeiger, E. (2003). HUMN project: Detailed description of the scoring criteria for the cytokinesis-block micronucleus assay using isolated human lymphocyte cultures. Mutation Research/Genetic Toxicology and Environmental Mutagenesis, 534(1-2), 65-75.

https://doi.org/10.1016/S1383-5718(02)00249-8

Frenzilli, G., Nigro, M., \& Lyons, B. (2009). The Comet assay for the evaluation of genotoxic impact in aquatic environments. Mutation Research/Reviews in Mutation Research, 681(1), 80-92. https://doi.org/10.1016/j.mrrev.2008.03.001
Frieden, E. (1972). The chemical elements of life. Scientific American, 227, 52-64.

Giri, A., Yadav, S. S., Giri, S., \& Sharma, G. D. (2012). Effect of predator stress and malathion on tadpoles of Indian skittering frog. Aquatic Toxicology, 106-107, 157-163.

https://doi.org/10.1016/j.aquatox.2011.11.008

Gosner, K. L. (1960). A simplified table for staging anuran embryos and larvae with notes on identification. Herpetologica, 16(3), 183-190.

Gupta, T., Talukder, G., \& Sharma, A. (1991). Cytotoxicity of zinc chloride in mice in vivo. Biological Trace Element Research, 30, 95-101. https://doi.org/10.1007/BF02990346

Haywood, L. K., Alexander, G. J., Byrne, M. J., \& Cukrowska, E. (2004). Xenopus laevis embryos and tadpoles as models for testing for pollution by zinc, copper, lead and cadmium. African Zoology, 39(2), 163-174.

https://doi.org/10.1080/15627020.2004.11657213

Ho, E., \& Ames, B. N. (2002). Low intracellular zinc induces oxidative DNA damage, disrupts p53, NFkB, and AP1 DNA binding, and affects DNA repair in a rat glioma cell line. Proceedings of the National Academy of Sciences, 99(26), 1677016775. https://doi.org/10.1073/pnas.222679399

Ho, E., Courtemanche, C., \& Ames, B. N. (2003). Zinc deficiency induces oxidative DNA damage and increases p53 expression in human lung fibroblasts. The Journal of Nutrition, 133(8), 2543-2548. https://doi.org/10.1093/jn/133.8.2543

Holcombe, G. W., Benoit, D. A., \& Leonard, E. N. (1979). Long term effects of zinc exposures on brook trout (Salvelinus fontinalis). Transactions of the American Fisheries Society, 108(1), 76-87.

https://doi.org/10.1577/1548-8659(1979)108<76:LEOZEO>2.0. $\mathrm{CO} ; 2$

Hopkins, W. A., Congdon, J., \& Ray, J. K. (2000). Incidence and impact of axial malformations in larval bullfrogs (Rana catesbeiana) developing in sites polluted by a coal-burning power plant. Environmental Toxicology and Chemistry, 19(4), 862-868. https://doi.org/10.1002/etc.5620190412

Khangarot, B., \& Ray, P. (1987). Sensitivity of toad tadpoles, Bufo melanostictus (Schneider), to heavy metals. Bulletin of Environmental Contamination and Toxicology, 38, 523-527. https://doi.org/10.1007/BF01606623

Khangarot, B., Sehgal, A., \& Bhasin, M. (1985). "Man and Biosphere" - Studies on the Sikkim Himalayas. Part 5: Acute toxicity of selected heavy metals on the tadpoles of Rana hexadactyla. Acta hydrochimica et hydrobiologica, 13(2), 259-263. https://doi.org/10.1002/aheh.19850130223

Kowalska-Wochna, E., Moniuszko-Jakoniuk, J., Kulikowska, E., \& Miniuk, K. (1988). The effect of orally applied aqueous solutions of lead and zinc on chromosome aberrations and induction of sister chromatid exchanges in the rat (Rattus sp.). Genetica Polonica, 29(2), 181-189.

Lajmanovich, R. C., Cabagna, M., Peltzer, P. M., Stringhini, G. A., \& Attademo, A. M. (2005). Micronucleus induction in erythrocytes of the Hyla pulchella tadpoles (Amphibia: Hylidae) exposed to insecticide endosulfan. Mutation Research/ Genetic Toxicology and Environmental Mutagenesis, 587(1-2), 67-72. https://doi.org/10.1016/j.mrgentox.2005.08.001

Lefcort, H., Meguire, R., Wilson, L., \& Ettinger, W. (1998). Heavy metals alter the survival, growth, metamorphosis, and antipredatory behavior of Columbia spotted frog (Rana luteiventris) tadpoles. Archives of Environmental Contamination and Toxicology, 35, 447-456. https://doi.org/10.1007/s002449900401 
Leland, H. V. (1983). Ultrastructural changes in the hepatocytes of juvenile rainbow trout and mature brown trout exposed to copper or zinc. Environmental Toxicology and Chemistry, 2(3), 353-368. https://doi.org/10.1002/etc.5620020312

Linder, G., \& Grillitsch, B. (2000). Ecotoxicology of metals. In D. W. Sparling, G. Linder, \& C. A. Bishop (Eds.), Ecotoxicology of amphibians and reptiles (pp. 325-459). SETAC Press.

Mohiuddin, K., Ogawa, Y., Zakir, H., Otomo, K., \& Shikazono, N. (2011). Heavy metals contamination in water and sediments of an urban river in a developing country. International Journal of Environmental Science \& Technology, 8, 723-736. https://doi.org/10.1007/BF03326257

Mondal, P., Reichelt-Brushett, A. J., Jonathan, M. P., Sujitha, S. B., \& Sarkar, S. K. (2017). Pollution evaluation of total and acidleachable trace elements in surface sediments of Hooghly River Estuary and Sundarban Mangrove Wetland (India). Environmental Science and Pollution Research, 25(6), 5681-5699. https://doi.org/10.1007/s11356-017-0915-0

Montalvão, M. F., \& Malafaia, G. (2017). Effects of abamectin on bullfrog tadpoles: insights on cytotoxicity. Environmental Science and Pollution Research, 24, 23411-23416.

https://doi.org/10.1007/s11356-017-0124-x

Mouchet, F. (2002). Validation du test comete sur larves d'amphibiens (xenopus laevis et Pleurodeles Waltl) et application al'évaluation du potentiel génotoxique de sols, sédiments et déchets contaminés. Comparaison avec filetest micronoyau amphibien [These de doctorat de l'Université Paul Sabatier de Toulouse]. Centre de Biologie du Développement.

Mouchet, F., Baudrimont, M., Gonzalez, P., Cuenot, Y., Bourdineaud, J.-P., Boudou, A., \& Gauthier, L. (2006). Genotoxic and stress inductive potential of cadmium in Xenopus laevis larvae. Aquatic Toxicology, 78(2), 157-166.

https://doi.org/10.1016/j.aquatox.2006.02.029

Mouchet, F., Gauthier, L., Baudrimont, M., Gonzalez, P., Mailhes, C., Ferrier, V., \& Devaux, A. (2007). Comparative evaluation of the toxicity and genotoxicity of cadmium in amphibian larvae (Xenopus laevis and Pleurodeles waltl) using the comet assay and the micronucleus test. Environmental Toxicology, 22(4), 422-435. https://doi.org/10.1002/tox.20267

Mouchet, F., Gauthier, L., Mailhes, C., Ferrier, V., \& Devaux, A. (2005). Comparative study of the comet assay and the micronucleus test in amphibian larvae (Xenopus laevis) using benzo (a) pyrene, ethyl methanesulfonate, and methyl methanesulfonate: Establishment of a positive control in the amphibian comet assay. Environmental Toxicology, 20(1), 74-84. https://doi.org/10.1002/tox.20080

Muranli, F. D. G., \& Güner, U. (2011). Induction of micronuclei and nuclear abnormalities in erythrocytes of mosquito fish (Gambusia affinis) following exposure to the pyrethroid insecticide lambda-cyhalothrin. Mutation Research/Genetic Toxicology and Environmental Mutagenesis, 726(2), 104-108. https://doi.org/10.1016/j.mrgentox.2011.05.004

Nzengue, Y., Candéias, S. M., Sauvaigo, S., Douki, T., Favier, A., Rachidi, W., \& Guiraud, P. (2011). The toxicity redox mechanisms of cadmium alone or together with copper and zinc homeostasis alteration: its redox biomarkers. Journal of Trace Elements in Medicine and Biology, 25(3), 171-180.

https://doi.org/10.1016/j.jtemb.2011.06.002

Obiakor, M., Okonkwo, J., Ezeonyejiaku, C., \& Ezenwelu, C. (2010). Genotoxicology: Single and joint action of copper and zinc to Synodontis clarias and Tilapia nilotica. Journal of Applied Sciences and Environmental Management, 14(3), 59-64. https://doi.org/10.4314/jasem.v14i3.61468
Patar, A., Giri, A., Boro, F., Bhuyan, K., Singha, U., \& Giri, S. (2016). Cadmium pollution and amphibians-Studies in tadpoles of Rana limnocharis. Chemosphere, 144, 1043-1049. https://doi.org/10.1016/j.chemosphere.2015.09.088

Purushothaman, P., \& Chakrapani, G. (2007). Heavy metals fractionation in Ganga River sediments, India. Environmental Monitoring and Assessment, 132, 475-489.

https://doi.org/10.1007/s10661-006-9550-9

Rowe, C. L., Kinney, O. M., Nagle, R. D., \& Congdon, J. D. (1998). Elevated maintenance costs in an anuran (Rana catesbeiana) exposed to a mixture of trace elements during the embryonic and early larval periods. Physiological and Biochemical Zoology, 71(1), 27-35. https://doi.org/10.1086/515885

Sarkar, S. K., Mondal, P., Biswas, J. K., Kwon, E. E., Ok, Y. S., \& Rinklebe, J. (2017). Trace elements in surface sediments of the Hooghly (Ganges) estuary: Distribution and contamination risk assessment. Environmental Geochemistry and Health, 39(6), 1245-1258. https://doi.org/10.1007/s10653-017-9952-3

Shuhaimi-Othman, M., Nadzifah, Y., Umirah, N., \& Ahmad, A. (2012). Toxicity of metals to tadpoles of the common Sunda toad, Duttaphrynus melanostictus. Toxicological \& Environmental Chemistry, 94(2), 364-376.

https://doi.org/10.1080/02772248.2011.640636

Singh, N. P., McCoy, M. T., Tice, R. R., \& Schneider, E. L. (1988). A simple technique for quantitation of low levels of DNA damage in individual cells. Experimental Cell Research, 175(1), 184-191. https://doi.org/10.1016/0014-4827(88)90265-0

Singha, U., Pandey, N., Boro, F., Giri, S., Giri, A., \& Biswas, S. (2014). Sodium arsenite induced changes in survival, growth, metamorphosis and genotoxicity in the Indian cricket frog (Rana limnocharis). Chemosphere, 112, 333-339. https://doi.org/10.1016/j.chemosphere.2014.04.076

Sinley, J. R., Goettl, J. P., \& Davies, P. H. (1974). The effects of zinc on rainbow trout (Salmo gairdneri) in hard and soft water. Bulletin of Environmental Contamination and Toxicology, 12, 193-201. https://doi.org/10.1007/BF01684960

Skidmore, J. (1964). Toxicity of zinc compounds to aquatic animals, with special reference to fish. The Quarterly Review of Biology, 39(3), 227-248. https://doi.org/10.1086/404229

Skordas, K., Kelepertzis, E., Kosmidis, D., Panagiotaki, P., \& Vafidis, D. (2015). Assessment of nutrients and heavy metals in the surface sediments of the artificially lake water reservoir Karla, Thessaly, Greece. Environmental Earth Sciences, 73, 4483-4493. https://doi.org/10.1007/s12665-014-3736-1

Sliwinski, T., Czechowska, A., Kolodziejczak, M., Jajte, J., Wisniewska-Jarosinska, M., \& Blasiak, J. (2009). Zinc salts differentially modulate DNA damage in normal and cancer cells. Cell Biology International, 33(4), 542-547. https://doi.org/10.1016/j.cellbi.2009.02.004

Stebler, E. F., Burks, S. L., Bantle, J. A., \& Dawson, D. A. (1988). Evaluation of the developmental toxicity of metal-contaminated sediments using short term fathead minnow and frog embryo larval assays. Environmental Toxicology and Chemistry, 7(1), 27-34. https://doi.org/10.1002/etc.5620070105

Stuart, S. N., Chanson, J. S., Cox, N. A., Young, B. E., Rodrigues, A. S., Fischman, D. L., \& Waller, R. W. (2004). Status and trends of amphibian declines and extinctions worldwide. Science, 306(5702), 1783-1786.

https://doi.org/10.1126/science.1103538

Svecevičius, G. (1999). Fish avoidance response to heavy metals and their mixtures. Acta Zoologica Lituanica, 9(2), 103-113. https://doi.org/10.1080/13921657.1999.10512293

Tice, R. R., Agurell, E., Anderson, D., Burlinson, B., Hartmann, A., Kobayashi, H., Miyamae, Y., Rojas, E., Ryu, J. C., 
\& Sasaki, Y. (2000). Single cell gel/comet assay: Guidelines for in vitro and in vivo genetic toxicology testing. Environmental and Molecular Mutagenesis, 35(3), 206-221.

https://doi.org/10.1002/(SICI)1098-2280(2000)35:3<206::AIDEM8>3.0.CO;2-J

Vilkina, G., Pomerantseva, M., \& Ramaŭia, L. (1978). Absence of a mutagenic effect of cadmium and zinc salts in mouse somatic and sex cells. Genetika, 14, 2212-2214.

Vladimirov, V. (1969). Dependence of the embryonic development and viability of the carp on the trace element zinc. Voprosy Ikhtiologii, 9, 687-696.

Voroshilin, S., Plotko, E., Fink, T., \& Nikiforova, V. (1978). Cytogenetic effect of inorganic compounds of tungsten, zinc, cadmium and cobalt on animal and human somatic cells. TSitologiia i genetika, 241-243.

Wei, B., \& Yang, L. (2010). A review of heavy metal contaminations in urban soils, urban road dusts and agricultural soils from China. Microchemical Journal, 94(2), 99-107. https://doi.org/10.1016/j.microc.2009.09.014

Wei, L., Ding, G., Guo, S., Tong, M., Chen, W., Flanders, J., Shao, W., \& Lin, Z. (2015). Toxic effects of three heavy metallic ions on Rana zhenhaiensis tadpoles. Asian Herpetological Research, 6(2), 132-142.
World Health Organization. (2001). International programme on chemical safety (Environmental Health Criteria 221). Geneva.

Xie, H., Holmes, A. L., Young, J. L., Qin, Q., Joyce, K., Pelsue, S. C., Peng, C., Wise, S. S., Jeevarajan, A. S., Wallace, W. T., Hammond, D., \& Sr, J. P. W. (2009). Zinc chromate induces chromosome instability and DNA double strand breaks in human lung cells. Toxicology and Applied Pharmacology, 234(3), 293-299. https://doi.org/10.1016/j.taap.2008.10.010

Yadav, S. S., Giri, S., Singha, U., Boro, F., \& Giri, A. (2013). Toxic and genotoxic effects of Roundup on tadpoles of the Indian skittering frog (Euflictis cyanophlyctis) in the presence and absence of predator stress. Aquatic Toxicology, 132, 1-8. https://doi.org/10.1016/j.aquatox.2013.01.016

Yulin, W., Hongru, Z., \& Lanying, H. (1990). Effects of heavy metals on embryos and larvae of flat fish paralichthys olivaceus [j]. Oceanologia et Limnologia Sinica, 21, 386-392.

Zhang, Y., Wang, Y., Yu, R., Zhang, S., \& Wu, Z. (2008). Effects of heavy metals $\mathrm{Cd}^{2+}, \mathrm{Pb}^{2+}$ and $\mathrm{Zn}^{2+}$ on DNA damage of loach Misgurnus anguillicaudatus. Frontiers of Biology in China, 3, 50-54. https://doi.org/10.1007/s11515-008-0012-3 